\title{
Advancing the application of remote sensing for forest informa- tion needs in Canada: Lessons learned from a national collabora- tion of university, industrial and government stakeholders
}

\author{
by Nicholas C. Coops ${ }^{1 *}$, Alexis Achim², Paul Arp ${ }^{3}$, Christopher W. Bater ${ }^{4}$, John P. Caspersen ${ }^{5}$, Jean-François Côté6, \\ Jeffery P. Dech ${ }^{7}$, Adam R. Dick ${ }^{8}$, Karin van Ewijk ${ }^{9}$, Richard Fournier ${ }^{10}$, Tristan R. H. Goodbody ${ }^{1}$, Chris R. Hennigar ${ }^{11}$, \\ Antoine Leboeuf ${ }^{12}$, Olivier R. van Lier ${ }^{13}$, Joan E. Luther ${ }^{14}$, David A. MacLean ${ }^{3}$, Grant McCartney ${ }^{15}$, Gaetan Pelletier ${ }^{16}$, \\ Jean-Francois Prieur ${ }^{10}$, Piotr Tompalski ${ }^{1}$, Paul M. Treitz ${ }^{9}$, Joanne C. White ${ }^{17}$, Murray E. Woods ${ }^{18}$
}

\begin{abstract}
The Canadian forest sector requires detailed information regarding the amount and characteristics of the forest resource. To address these needs, inventory systems that spatially quantify timber and other forest related ecosystem services are required, that are accurate, comprehensive and timely. The Assessment of Wood properties using Remote Sensing (AWARE) was a five-year project involving collaboration between seven Canadian universities, and seven forest companies with support provided by provincial and federal forestry agencies and other non-for-profit forestry focused organisations. AWARE provided methods and tools to enhance the characterization of forests at national, landscape and individual tree scales. The project supported 24 post-doctoral fellows, $\mathrm{PhD}$ and MSc students that examined the roles that advanced three-dimensional remote sensing technologies can play in the development of accurate forest inventory systems across Canada. In this review we examine the AWARE research project, review research highlights, key outcomes, future research needs, and provide an assessment of successes and challenges the project faced over its five-year lifetime.
\end{abstract}

Keywords: forest inventory, Airborne Laser Scanning, ALS, terrestrial, remote sensing

\section{RÉSUMÉ}

Le secteur forestier canadien a besoin d'information détaillée au sujet de la quantité et des caractéristiques des ressources forestières. Pour répondre à de tels besoins, des systèmes d'inventaire exacts, complets et opportuns qui quantifient spatialement le bois d'œuvre et les autres services écosystémiques liés aux forêts sont nécessaires. Le projet quinquennal AWARE (Assessment of Wood Attributes using Remote sEnsing [évaluation des attributs du bois à l'aide de la télédétection]) était une collaboration entre sept universités canadiennes et sept entreprises forestières soutenue par des organismes forestiers provinciaux et fédéraux et d'autres organismes sans but lucratif-axés sur la foresterie. AWARE a fourni des méthodes et des outils pour améliorer la caractérisation des forêts à une échelle nationale, du paysage et de l'arbre individuel. Vingt-quatre boursiers de recherches postdoctorales et étudiants au doctorat et à la maîtrise se sont associés au projet et ont examiné les rôles que les technologies de télédétection tridimensionnelle (3D) de pointe peuvent jouer dans la conception de systèmes d'inventaire forestier précis partout au Canada. Dans le présent article de revue, nous nous penchons sur le projet de recherche AWARE, les points saillants de la recherche, les résultats clés et les besoins futurs en recherche et présentons une évaluation des réussites et des défis auxquels le projet a été confronté au cours de ses cinq ans.

Mots-clés : inventaire forestier, balayage laser aéroporté, BLA, terrestre, télédétection

\footnotetext{
${ }^{1}$ Integrated Remote Sensing Studio, Department of Forest Resources Management, University of British Columbia, 2424 Main Mall, Vancouver, BC, V6T 1Z4, Canada. ${ }^{*}$ Correspondence: Nicholas.coops@ubc.ca

${ }^{2}$ Centre de recherche sur les matériaux renouvelables, Département des sciences du bois et de la forêt, Université Laval, 2425 rue de la Terrasse, Québec, QC, G1V 0A6, Canada.

${ }^{3}$ Faculty of Forestry and Environmental Management, University of New Brunswick, 2 Bailey Dr., Fredericton, NB, E3B 5A3, Canada.

${ }^{4}$ Forest Stewardship and Trade Branch, Forestry Division, Alberta Agriculture and Forestry, Suite 303, 7000-113 Street, Edmonton, AB, T6H 5T6, Canada.

${ }^{5}$ Institute of Forestry and Conservation, Graduate Department of Forestry, John H. Daniels Faculty of Architecture, Landscape and Design, University of Toronto. 1 Spadina Crescent, Toronto, ON, M5S 2J5, Canada.

6Natural Resources Canada, Canadian Forest Service - Canadian Wood Fibre Centre, 1055 rue du P.E.P.S., Québec, QC, G1V 4C7, Canada.

${ }^{7}$ Department of Biology and Chemistry, Nipissing University, 100 College Drive, North Bay, ON, P1B 8L7, Canada.

${ }^{8}$ Natural Resources Canada, Canadian Forest Service, Canadian Wood Fibre Centre, 1350 Regent Street, Fredericton, New Brunswick, E3B 5P7, Canada.

${ }^{9}$ Department of Geography and Planning, Queen's University, 68 University Avenue, Kingston, ON, K7L 3N6, Canada.

${ }^{10}$ Département de géomatique appliquée, Centre d'Applications et de Recherches en Télédétection (CARTEL), Université de Sherbrooke, 2500 Boulevard de l'Université, Sherbrooke, QC, J1K 2R1 Canada.
} 


\footnotetext{
${ }^{11}$ New Brunswick Dept. of Nat. Res., Hugh John Flemming Forestry Centre, P. O. Box 6000, Fredericton, NB, E3B 5H1, Canada.

${ }^{12}$ Ministère des Forêts, de la Faune et des Parcs, 5700, 4ième Avenue Ouest, Québec, QC, G1H 6R1, Canada,

${ }^{13}$ Natural Resources Canada, Canadian Forest Service, Canadian Wood Fibre Centre, 26 University Drive, Corner Brook, NL, A2H 5G4, Canada.

${ }^{14}$ Natural Resources Canada, Canadian Forest Service, Atlantic Forestry Centre, 26 University Drive, Corner Brook, NL, A2H 5G4, Canada.

${ }^{15}$ Chief Forester's Group - Ontario, RYAM Forest Management, Rayonier Advanced Materials, Unit 203 - 37 Preston Street, Timmins, ON, P4N 3M7, Canada.

${ }^{16}$ Northern Hardwoods Research Institute, 165 Boulevard Hébert, Edmundston, NB, E3V 2S8, Canada.

${ }^{17}$ Natural Resources Canada, Canadian Forest Service, Pacific Forestry Centre, 506 West Burnside Road, Victoria, BC, V8Z 1M5, Canada.

${ }^{18}$ Retired - Natural Resources Information Section, Science and Research Branch, Ontario Ministry of Natural Resources and Forestry, North Bay, Ontario P1A 4L7, Canada.
}

\section{Introduction}

The Canadian forest industry is required to respond to rapidly changing pressures within the forest sector to satisfy an increasingly complex set of rules, standards, business practices, and public expectations (i.e., economic, environmental and social policy goals). As a result, the forestry sector must generate the maximum possible value from each tree harvested, while practicing sustainable forest management. Knowledge of stand, site, and tree attributes is of paramount importance to forest managers and can impact decisions along the entire forest value chain (Fridman et al. 2014). Tree species mix, stand age, and site index are used to estimate, or predict, the potential quality and quantity of timber available to serve various market demands. The economic value of harvested timber depends on its end-use, and is largely affected by a variety of factors including the species mix, quality of the wood fibre and stem-size dimensions. Accurate, consistent, and reliable information on the quality of the forest resource at the landscape, stand, and individual tree level prior to harvest is of enormous benefit to the forestry sector, enabling the optimization of harvesting and marketing strategies. Within Canada, provincial and territorial governments have implemented forest inventory programs according to their own standards and information requirements (Leckie and Gillis 1995; Magnussen et al. 2017). These forest inventories are primarily designed for management unit planning (Gillis 2001) and serve multiple resource management objectives; however, conventional photo-interpreted polygons often lack the spatial resolution and attributes required to support the planning, management, and investment decisions that are necessary to enhance the competiveness of Canada's forest sector (White et al. 2016).

The lack of accurate and precise forest information is a significant barrier to adaptive and responsive forest management and hinders the timely provision of ecosystem service. There are two critical needs to address this barrier: first, to develop accurate inventory systems that spatially quantify timber and other forest-related ecosystem services, and second, to further the use of these systems to improve modelling of forested ecosystems, both with respect to accuracy and comprehensiveness. Recognizing the growing importance of accurate, timely and comprehensive inventory systems for forest management across Canada, the Canadian Wood Fibre Centre (CWFC) and FPInnovations, in collaboration with the Canadian Natural Sciences and Engineering Research Council (NSERC) called for applied proposals to improve the accuracy and precision of forest inventories while reducing costs and increasing speed of data acquisition. In response, a comprehensive five-year project (Assessment of Wood properties using Remote Sensing, AWARE) was developed involving collaboration between seven Canadian universities, and seven forest companies with support provided by provincial and federal forestry agencies and other non-for-profit forestry focused organisations. The proposal supported 24 post-doctoral fellows, $\mathrm{PhD}$ and MSc students and focused research on a number of core sites across Canada which represented a range of forest types, comprised areas of active forest management, and acquired datasets to support a wide variety of research questions.

In this review we document research highlights of the AWARE project and review the lessons learned about the application of remote sensing to forest information needs in Canada. We conduct a retrospective of the AWARE research program given its completion in March 2020 and revisit the project design, research questions posed, research outcomes and deliverables generated. We then provide an assessment of the successes and challenges, with respect to the overall research program and the collaborations among industry, government and universities. We further provide lessons learned and suggest recommendations for future large collaborative projects focused on meeting the needs of the Canadian forest industry.

\section{AWARE project design \\ Overview}

The AWARE project was devised in the early 2010s when remote sensing technologies had significantly advanced in their ability to measure and predict a range of stand, site, tree, and wood properties at a range of spatial scales. The AWARE project was designed with a focus on light detection and ranging (LiDAR) technologies, however, other remote sensing technologies such as digital aerial photogrammetry (DAP), and aerial and satellite optical data were also utilized in specific studies. LiDAR from terrestrial and airborne laser scanning (i.e., TLS and ALS respectively) instruments in particular allow for extremely detailed individual tree and standlevel data to be acquired (Vastaranta et al. 2012).

The AWARE project was defined as a series of themes (Fig. 1), recognizing that many of the project stakeholders had a range of information needs that varied across spatial scales. At the broadest spatial scale, federal and provincial agencies have responsibilities for reporting national and provincial trends in forest growth, condition, and quality. In contrast, at a stand scale, research outcomes are of interest for 


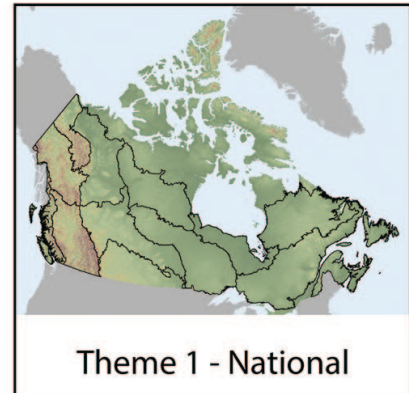

- Ecological drivers and implications for management

- Structural variability and wood properties

- Sampling approaches for regional

level reporting

\section{3 projects}

3 publications

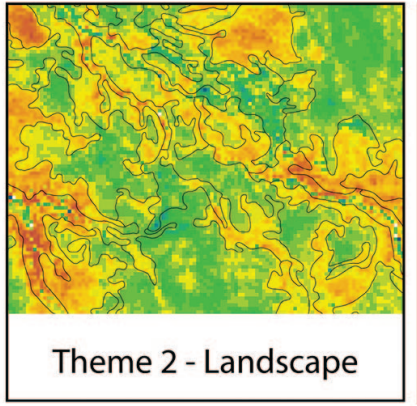

- Enhancing stand growth modeling - New structural metrics for forest stand descriptions

- Hydrological mapping and productivity

- Predictive modeling for ecological site classification, habitat, and forest health

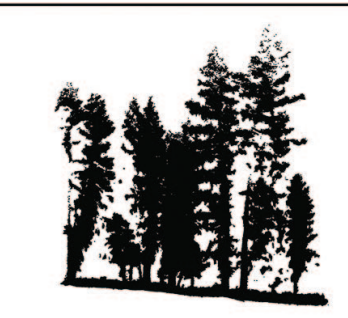

Theme 3 - Individual tree

- Growth assessment using single date and multitemporal TLS datasets

Tree attribute extraction and metrics

UAV and mobile lidar

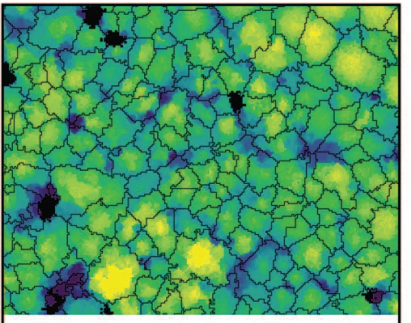

Theme 4 - Cross-cutting

- Species assessment

- New ITD approaches

- New point cloud processing tools

- Best practices, tools, and decision support

- Data acquisition program and platforms

Fig. 1. The four AWARE themes explored throughout the project. Note: individual tree delineation (ITD); terrestrial laser scanning (TLS); unmanned aerial vehicle (UAV).

tactical and operational inventories and management, including activities such as growth and yield modelling, and silviculture. Lastly, at the individual tree scale, tree attributes can be used to both inform on stem quality and provide valuable information, such as allometry, which can then feed into plot and national level biomass and stand structure estimates. In addition to these three research themes, a cross-cutting theme focused on development of standards and delivery mechanisms (i.e., data acquisition, standards specifications) for these advanced remote sensing datasets and resulting information products, as well as the generation of demonstration datasets and case studies. Core research sites were established in Newfoundland, New Brunswick, Ontario and Alberta covering a range of forest types and productivities across Canada (Table 1).

\section{National-level research questions}

At the national level, research projects were focused on the relative impact of ecological drivers such as disturbance, productivity and management on broad-scale variations in stand structure. This included projects investigating the potential of LiDAR to provide a more thorough understanding of how stand structure can be affected by ecological drivers, including climate change, e.g., the stability of the northern tree line or the effect of disturbance, principally fire, on a broad range of stand structures across chronosequences.

\section{Landscape-level research questions}

At the landscape management scale, questions focused on how LiDAR and other remote sensing datasets can be applied to improve inventory programs. These questions were grouped into four sub-themes. The first sub-theme focused on the development of an improved understanding of how the relationship between key LiDAR point-cloud metrics change with field measures of structure as they are applied across different forest environments. This involved a comparison of LIDAR point-cloud metrics across sites, but also on how transferable models which relate point-cloud metrics to forest attributes (e.g., volume), through an area based approach (ABA), and vary from one site to another. The second sub-theme focused on forest growth estimation and the utilization of LIDAR and other three-dimensional (3D) remote sensing technologies to assess growth over time. A variety of studies applying a range of methodologies were undertaken, including comparing estimates of height and volume at two time steps and computing the difference, incorporating LiDAR observations into existing growth models, as well as imputation approaches which allow plot level data to be re-distributed across the landscape and linked to individual tree growth models. The third sub-theme focused on improving our understanding of the soil properties associated with tree and stand growth by taking advantage of fine-scaled digital terrain models (DTMs) acquired using LiDAR and predicting a range of soil attributes which can inform on both plantation growth and management. Lastly, a series of questions were focused on the estimation of a range of forest ecological goods and services that can be derived from LiDAR and other remote sensing data sets including habitat, forest health and site classification.

\section{Individual tree-based research questions}

At the individual tree scale, projects focused on the extraction of individual attributes from fine-scale LiDAR observations acquired from either ground-based or UAV-based platforms. 
Table 1. Core research sites established for the AWARE project from east to west across Canada

\begin{tabular}{|c|c|c|c|c|c|}
\hline Location & Area & Forest type & $\begin{array}{l}\text { Industrial } \\
\text { Partner }\end{array}$ & $\begin{array}{l}\text { Main 3D Remote } \\
\text { Sensing data used } \\
\text { in AWARE }\end{array}$ & Field Data \\
\hline $\begin{array}{l}\text { Harry's River } \\
\text { Watershed NL }\end{array}$ & 95000 ha & $\begin{array}{l}\text { Boreal } \\
\text { coniferous }\end{array}$ & $\begin{array}{l}\text { Corner Brook Pulp } \\
\text { and Paper Limited }\end{array}$ & $\begin{array}{l}\text { ALS }\left(2016,7.3 \text { points } / \mathrm{m}^{2}\right) \\
\text { TLS }(2009-2010,227 \text { trees } \\
\text { over } 68 \text { plots })\end{array}$ & $\begin{array}{l}\text { CFS and AWARE } \\
\text { inventory plots }\end{array}$ \\
\hline $\begin{array}{l}\text { Black Brook } \\
\text { District, NB }\end{array}$ & 200000 ha & $\begin{array}{l}\text { Acadian } \\
\text { mixedwood }\end{array}$ & JD Irving Limited & $\operatorname{ALS}(2011,20136$ points/m²) & $\begin{array}{l}\text { JD Irving Limited } \\
\text { Inventory plots and } \\
\text { AWARE individual } \\
\text { tree maps }\end{array}$ \\
\hline $\begin{array}{l}\text { Hearst Forest } \\
\text { Manage. Area, } \\
\text { ON }\end{array}$ & 1250000 ha & Boreal & $\begin{array}{l}\text { Ryam Forest } \\
\text { Management/ Lecours } \\
\text { Lumber/ Columbia } \\
\text { Forest Products }\end{array}$ & $\operatorname{ALS}\left(2007,0.82\right.$ points $\left./ \mathrm{m}^{2}\right)$ & $\begin{array}{l}\text { Ryam Forest Manage- } \\
\text { ment and provincial and } \\
\text { AWARE inventory plots. }\end{array}$ \\
\hline $\begin{array}{l}\text { Gordon } \\
\text { Cousins, ON }\end{array}$ & 1880369 ha & Boreal & $\begin{array}{l}\text { Ryam Forest } \\
\text { Management }\end{array}$ & DAP $\left(2016,4.3\right.$ points $\left./ \mathrm{m}^{2}\right)$ & $\begin{array}{l}\text { Ryam Forest Manage- } \\
\text { ment and provincial and } \\
\text { AWARE inventory plots. }\end{array}$ \\
\hline $\begin{array}{l}\text { Petawawa } \\
\text { Research } \\
\text { Forest, ON }\end{array}$ & 10000 ha & Mixedwood & CFS & $\begin{array}{l}\text { Multispectral ALS }(2016 ; 4.1 \\
-10.0 \text { points } / \mathrm{m}^{2} \text { depending on } \\
\text { the spectral band }\end{array}$ & $\begin{array}{l}\text { CFS long term, and } \\
\text { AWARE, inventory plots. }\end{array}$ \\
\hline $\begin{array}{l}\text { Slave Lake } \\
\text { Forest, AB }\end{array}$ & 700000 ha & $\begin{array}{l}\text { Boreal } \\
\text { mixedwood }\end{array}$ & West Fraser & $\begin{array}{l}\text { ALS }\left(2006-2008,1.63 \text { points } / \mathrm{m}^{2}\right) \\
\text { DAP }\left(2015,0.82 \text { points } / \mathrm{m}^{2}\right)\end{array}$ & $\begin{array}{l}\text { West Fraser, Provincial } \\
\text { and AWARE inventory } \\
\text { plots }\end{array}$ \\
\hline
\end{tabular}

Note: Airborne laser scanning (ALS), digital aerial photogrammetry (DAP), Canadian Forest Service (CFS)

These projects were designed to link individual tree level attributes derived from LiDAR such as branching architecture, diameter, and taper, to determine how these LiDARderived tree attributes can inform plot and stand-level estimates of structure. LiDAR data were acquired at a range of point densities from a variety of sensors and platforms. As a result, we were able to examine multiple data processing approaches to assess the impact of data acquisition parameters on derived metrics and modelled variables.

\section{Cross-cutting research questions}

The final theme was focused on issues that were common across many forest management companies and governments in Canada and across spatial scales around the effective use of remote sensing technologies. These included the development of new routines to extract individual tree crowns from high density LiDAR point clouds acquired from aircraft as well as individual species predictions on the extracted crowns in an optimized and cost effective way. This theme also saw the development of a, now widely used, $\mathrm{R}$ package for LIDAR data processing to help users of LiDAR and other 3D remote sensing datasets efficiently and effectively process LiDAR data.

\section{AWARE research highlights}

Through the five-year time frame of AWARE the project produced useful and important outcomes with respect to graduate-level education and training, technology transfer from universities to industry and government, publishing of world-class research in leading academic journals, and producing outcomes useful for forest management companies. We provide a short synthesis of select research outcomes below, both to highlight advances and to suggest where future LiDAR-based research initiatives in Canada could continue to facilitate business solutions. At the time of preparing this publication, a variety of knowledge transfer activities, software packages (Table 2) and a total of 40 scientific papers describing AWARE research were published (Table 3), with a small number remaining in preparation. 
Table 2. AWARE resources and knowledge exchange

\begin{tabular}{lll}
\hline & What is it & Where \\
\hline & Data & \\
\hline $\begin{array}{l}\text { Petawawa Research } \\
\text { Forest Supersite }\end{array}$ & $\begin{array}{l}\text { Archive of MLS and plot data } \\
\text { acquired at the PRF }\end{array}$ & $\begin{array}{l}\text { https://opendata.nfis.org/mapserver/PRF.html } \\
\text { White } \text { et al. (2019) }\end{array}$ \\
\begin{tabular}{l} 
CWFC) \\
\hline
\end{tabular} & & \\
\hline
\end{tabular}

Knowledge Exchange

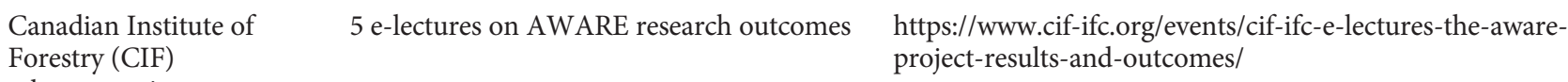

Forestry (CIF)

e-lecture series

Code / Packages

\begin{tabular}{ll}
\hline lidR & $\begin{array}{l}\text { A package written for the } \mathrm{R} \\
\text { programming environment for } \\
\text { processing lidR data }\end{array}$
\end{tabular}

Foster A package written for the $\mathrm{R}$ programming environment for

github.com/mqueinnec/foster extrapolation of LiDAR data over larger areas using interpolation

SEGMA Individual Tree delineation algorithm Please contact authors

While all of the research stemming from AWARE is available, in either publications or student theses, here we present four highlights that demonstrate how the research within AWARE contributed directly to improvements in forest inventory and other aspects of sustainable forestry. The four highlights described below summarize research on: (1) using point-cloud datasets to improve forest growth modeling; (2) individual tree level analysis and species classification; (3) extracting detailed information on individual trees and plots with TLS; and, finally (4) how 3D remote sensing data can be used beyond conventional forest inventory to predict additional more ecologically focused forest attributes.

\section{Use of 3D remote sensing data to predict forest growth The AWARE approach}

The increased availability of 3D point clouds, including both ALS and DAP, allows for the derivation of forest inventory information with a high level of attribute accuracy and spatial detail. Multi-temporal acquisition of point-cloud datasets over the same area are becoming more and more common, facilitating detailed analysis of change in forest structure over time. When utilized in an enhanced forest inventory (EFI), estimates provided by ALS or DAP have advantages over conventional photo-interpreted polygonal inventory datasets, however limitations that are important to consider for forest growth modelling typically involve the lack of ability to accurately predict stand age or tree species composition, both of which are critical components of forest growth and yield models. Within AWARE, a range of methodologies to characterize forest growth were examined. Those included methods used to retrospectively estimate growth rates based on two or more measurements in time and methods to forecast stand attributes by integrating multi-temporal point-cloud datasets with growth simulators. In the first category, change between data acquisitions is characterized using point cloud-based change detection as well as cell- and tree-level estimates of growth. The second category includes methods that incorporate observed growth rates in forest attributes from point clouds into existing forest productivity growth and yield models, as well as leveraging change information to develop new models for forecasting future stand attributes.

The most straightforward case of using multi-temporal point-cloud datasets to retrospectively characterize growth is detecting changes in point-cloud metrics or estimated celllevel attributes. These changes can be characterized by using two different approaches. In the indirect approach, independent models are used to derive predictions of forest attributes which are then subtracted from each other. In the direct approach, a single model is developed to estimate the change in forest attributes utilizing change in metrics as predictors. Both approaches were used and compared at the Slave Lake site. Low density ALS and DAP point clouds informing on stand structure at T1 and T2, respectively, were used to quantify changes in top height $(\mathrm{H})$, volume $(\mathrm{V})$ and basal area (BA). Tompalski et al. 2009 showed that analysis of growth in a highly disturbed and slow growing boreal forest is often challenging. The highest accuracy of growth estimates was reported when the direct approach was used, with an $\mathrm{R}^{2}$ of 0.60 for change in $\mathrm{H}$. The accuracy of the estimates generated using the indirect approach was markedly lower, with especially poor results for $\triangle \mathrm{BA}$ and $\Delta \mathrm{V}$. While both ALS and DAP facilitated developing predictive models of forest attributes at T1 and T2, because of the slow growth and high 
Table 3. List of published or in press peer-reviewed papers covering AWARE research, including authors, AWARE theme, datasets used, focus site and short summaries

\begin{tabular}{|c|c|c|c|c|}
\hline Publication & $\begin{array}{l}\text { AWARE } \\
\text { Theme }\end{array}$ & Type of data used & AWARE site & Publication summary \\
\hline Bolton et al. 2018 & 1 & ALS, Landsat & Cross-Canada & $\begin{array}{l}\text { ALS data and Landsat time-series data used } \\
\text { to characterize alpine treeline ecotones and } \\
\text { ecosystem changes }\end{array}$ \\
\hline Bolton et al. 2020 & 1 & ALS, Landsat & $\begin{array}{l}\text { Harry's River Watershed, } \\
\text { Hearst, Petawawa } \\
\text { Forest, Research } \\
\text { Slave Lake (AB) }\end{array}$ & $\begin{array}{l}\text { ALS data and Landsat time-series data com- } \\
\text { bined estimate forest attributes across a range } \\
\text { of conditions }\end{array}$ \\
\hline $\begin{array}{l}\text { Budei and } \\
\text { St-Onge } 2018\end{array}$ & 4 & Multispectral ALS & $\begin{array}{l}\text { York Regional } \\
\text { Forest }(\mathrm{ON})\end{array}$ & $\begin{array}{l}\text { Demonstrated how height influences the ALS } \\
\text { 3D and intensity features }\end{array}$ \\
\hline Budei et al. 2018 & 4 & Multispectral ALS & $\begin{array}{l}\text { Scarborough }(\mathrm{ON}) \\
\text { York Regional } \\
\text { Forest }(\mathrm{ON})\end{array}$ & $\begin{array}{l}\text { Assessment of the accuracy of discrete return } \\
\text { multispectral ALS for identifying the species }\end{array}$ \\
\hline Coops et al. 2021 & 1 & ALS, Landsat & Cross-Canada & $\begin{array}{l}\text { Global review of approaches to extend ALS / } \\
\text { satellite based observations over large areas }\end{array}$ \\
\hline Côté et al. 2018 & 3 & $\begin{array}{l}\text { TLS, ALS, } \\
\text { L-Architect }\end{array}$ & Newfoundland Wide & $\begin{array}{l}\text { Demonstrated the capability to improve } \\
\text { haracterization of forest inventory attributes } \\
\text { using TLS and ALS data }\end{array}$ \\
\hline Côté et al. 2020 & 3 & TLS & $\begin{array}{l}\text { Harry's River } \\
\text { Watershed }\end{array}$ & $\begin{array}{l}\text { Examined which tree and stand structural } \\
\text { attributes are most useful to predict wood fibre } \\
\text { attributes at the tree level }\end{array}$ \\
\hline $\begin{array}{l}\text { Crespo-Peremarch } \\
\text { et al. } 2020\end{array}$ & 3 & $\begin{array}{l}\text { ALS (discrete \& full } \\
\text { waveform), TLS }\end{array}$ & $\begin{array}{l}\text { Harry's River } \\
\text { Watershed }\end{array}$ & $\begin{array}{l}\text { Investigated ability of ALS full waveform to } \\
\text { identify vegetation understory }\end{array}$ \\
\hline Donovan et al. 2018 & 2 & $\begin{array}{l}\text { Hemispherical } \\
\text { images }\end{array}$ & $\begin{array}{l}\text { Gaspé Peninsula, } \\
\text { Quebec }\end{array}$ & $\begin{array}{l}\text { Used and compare before and after hemi- } \\
\text { pherical images of crowns to quantify changes } \\
\text { in the foliage due to the spruce budworm } \\
\text { defoliation }\end{array}$ \\
\hline Donovan et al. 2021 & 2 & $\begin{array}{l}\text { Satellite hyperspectral } \\
\text { imagery }\end{array}$ & $\begin{array}{l}\text { Gaspé Peninsula, } \\
\text { Quebec }\end{array}$ & $\begin{array}{l}\text { Assessed predictive ability of satellite hyper- } \\
\text { spectral imagery to predict spruce budworm } \\
\text { defoliation classes }\end{array}$ \\
\hline Frizzle et al. 2021 & 2 & ALS & $\begin{array}{l}\text { Harry's River } \\
\text { Watershed }\end{array}$ & $\begin{array}{l}\text { Examined capacity of ALS derived DEM to } \\
\text { inform on water quality and runoff }\end{array}$ \\
\hline Furze et al. 2017a & 2 & ALS-derived DTM & Black Brook District & $\begin{array}{l}\text { Modelled and mapped productivity of black } \\
\text { and white spruce plantation using forest } \\
\text { attributes and DTMs }\end{array}$ \\
\hline Furze et al. 2017b & 2 & $\begin{array}{l}\text { ALS, Digital Elevation } \\
\text { Model (DEM) }\end{array}$ & Black Brook District & $\begin{array}{l}\text { Compared different sources of DEM data to } \\
\text { detect unmapped flow channels and wet areas }\end{array}$ \\
\hline $\begin{array}{l}\text { Goodbody et al. } \\
2018 \mathrm{a}\end{array}$ & 2 & DAP & Gordon Cosens Forest & $\begin{array}{l}\text { Assessed the ability of high spatial resolution } \\
\text { DAP data to predict cumulative defoliation in } \\
\text { spruce budworm host stands }\end{array}$ \\
\hline $\begin{array}{l}\text { Goodbody et al. } \\
2018 \text { b }\end{array}$ & 2 & UAS imagery & Edmundston & $\begin{array}{l}\text { Investigated the influence of flight acquisition } \\
\text { timing on the accuracy and coverage of DTMs } \\
\text { in low cover forest area }\end{array}$ \\
\hline Goodbody et al. 2019 & 2 & DAP & Cross-Canada & $\begin{array}{l}\text { Review of DAP as a tool for updating area- } \\
\text { based forest inventories }\end{array}$ \\
\hline Goodbody et al. 2020 & 4 & Multispectral ALS & $\begin{array}{l}\text { Petawawa Research } \\
\text { Forest }\end{array}$ & $\begin{array}{l}\text { Assessed the value of multispectral ALS for } \\
\text { modelling forest inventory attributes }\end{array}$ \\
\hline
\end{tabular}


Table 3. List of published or in press peer-reviewed papers covering AWARE research, including authors, AWARE theme, datasets used, focus site and short summaries (continued]

\begin{tabular}{|c|c|c|c|c|}
\hline Publication & $\begin{array}{l}\text { AWARE } \\
\text { Theme }\end{array}$ & Type of data used & AWARE site & Publication summary \\
\hline Goodbody et al. 2021 & 2 & ALS & Cross-Canada & $\begin{array}{l}\text { Review of the use of ALS for quantifying } \\
\text { criteria and indicators of sustainable forest } \\
\text { management }\end{array}$ \\
\hline Herniman et al. 2020 & 2 & ALS, Satellite images & $\begin{array}{l}\text { Harry's River } \\
\text { Watershed }\end{array}$ & $\begin{array}{l}\text { Combined ALS, plot surveys, imagery and } \\
\text { topographic data to quantify avian habitat } \\
\text { suitability }\end{array}$ \\
\hline Lamb et al. 2017 & 2 & ALS & Black Brook District & $\begin{array}{l}\text { Used ALS data to impute species-specific } \\
\text { tree-level inventory in tree or stand growth } \\
\text { models }\end{array}$ \\
\hline Lamb et al. 2018 & 2 & ALS & Black Brook District & $\begin{array}{l}\text { Developed new approach to predict forest } \\
\text { inventory variables using ALS }\end{array}$ \\
\hline Luther et al. 2019 & 1 & $\begin{array}{l}\text { ALS, Sentinel } 2 \text {, } \\
\text { PALSAR }\end{array}$ & $\begin{array}{l}\text { Harry's River Watershed } \\
\text { and surrounds }\end{array}$ & $\begin{array}{l}\text { ALS and medium resolution satellite data were } \\
\text { combined to extend forest attribute mapping }\end{array}$ \\
\hline Marczak et al. 2020 & 2 & ALS & $\begin{array}{l}\text { Petawawa Research } \\
\text { Forest }\end{array}$ & $\begin{array}{l}\text { Used growth and yield models based on ALS- } \\
\text { derived forests attributes to predict above- } \\
\text { ground carbon stock }\end{array}$ \\
\hline $\begin{array}{l}\text { Mulverhill et al. } \\
2018\end{array}$ & 2 & ALS & Slave Lake & $\begin{array}{l}\text { Evaluated which structural characteristics } \\
\text { derived from ALS data were best able to differ- } \\
\text { entiate between unimodal and bimodal stands }\end{array}$ \\
\hline $\begin{array}{l}\text { Mulverhill et al. } \\
\text { 2019a }\end{array}$ & 2 & $\begin{array}{l}\text { Digital Terrestrial } \\
\text { Photogrammetry } \\
\text { (DTP) }\end{array}$ & Slave Lake & $\begin{array}{l}\text { Evaluated the utility of digital terrestrial } \\
\text { photogrammetry to estimate stem volume } \\
\text { and taper }\end{array}$ \\
\hline Mulverhill et al. 2019b & 2 & ALS & Slave Lake & $\begin{array}{l}\text { Used ALS to evaluate differences in structural } \\
\text { development by species and disturbance types }\end{array}$ \\
\hline Mulverhill et al. 2020 & 2 & $\begin{array}{l}\text { Digital Terrestrial } \\
\text { Photogrammetry } \\
\text { (DTP) }\end{array}$ & Slave Lake & $\begin{array}{l}\text { Assessment of stand conditions using Digital } \\
\text { Terrestrial Photogrammetry }\end{array}$ \\
\hline Quinnec et al. 2021 & 4 & ALS & Canada Wide & $\begin{array}{l}\text { R package on extrapolating ALS data using } \\
\text { satellite optical data }\end{array}$ \\
\hline Nuijten et al. 2019 & 2 & DAP, UAS, ALS & $\begin{array}{l}\text { Edmundston, } \\
\text { New Brunswick }\end{array}$ & $\begin{array}{l}\text { Investigated the influence of the timing of DAP } \\
\text { acquisition on individual tree crown detection } \\
\text { accuracies }\end{array}$ \\
\hline Ravaglia et al. 2019 & 2 & TLS & $\begin{array}{l}\text { Newfoundland } \\
\text { (simulated data set), } \\
\text { Bas Saint-Laurent, } \\
\text { Quebec }\end{array}$ & $\begin{array}{l}\text { Developed an algorithm for TLS data estimate } \\
\text { diameter at breast height, stem diameter, and } \\
\text { trunk diameter }\end{array}$ \\
\hline Roussel et al. 2017 & 2 & ALS & $\begin{array}{l}\text { Haliburton Forest } \\
\text { and Wildlife Reserve, } \\
\text { Ontario }\end{array}$ & $\begin{array}{l}\text { Developed methods to compare } 2 \text { ALS datasets } \\
\text { with different pulses density for correcting } \\
\text { metrics used for an ABA }\end{array}$ \\
\hline Roussel et al. 2018 & 2 & ALS & $\begin{array}{l}\text { Haliburton Forest and } \\
\text { Wildlife Reserve }\end{array}$ & $\begin{array}{l}\text { Modelled effect of scan angle on prediction } \\
\text { bias of ALS metrics }\end{array}$ \\
\hline Roussel et al. 2020 & 4 & ALS & - & lidR package for the $\mathrm{R}$ environment \\
\hline Schmidt et al. 2020 & 2 & ALS & $\begin{array}{l}\text { Harry's River } \\
\text { Watershed }\end{array}$ & $\begin{array}{l}\text { Developed a framework to map ecosystem } \\
\text { services in support to forest management }\end{array}$ \\
\hline
\end{tabular}

ALS, Sentinel 2 ALS Photogrammetry

ALS Photogrammetry

ALS

Watershed
Review of the use of ALS for quantifying criteria and indicators of sustainable forest

Combined ALS, plot surveys, imagery and topographic data to quantify avian habita tree-level inventory in tree or stand growt Developed new approach to predict forest

ALS and medium resolution satellite data were Used growth and yield models based on ALS derived forests attributes to predict abovederived from ALS data were best able to differEvaluated the utility of digital terrestrial photogrammetry to estimate stem volume

Used ALS to evaluate differences in structural Assessment of stand conditions using Digital $\mathrm{R}$ package on extrapolating ALS data using Investigated the influence of the timing of DAP acquisition on individual tree crown detection services in support to forest management 
Table 3. List of published or in press peer-reviewed papers covering AWARE research, including authors, AWARE theme, datasets used, focus site and short summaries (continued)

\begin{tabular}{|c|c|c|c|c|}
\hline Publication & $\begin{array}{l}\text { AWARE } \\
\text { Theme }\end{array}$ & Type of data used & AWARE site & Publication summary \\
\hline Tompalski et al. 2018 & 2 & ALS, DAP & Slave Lake & $\begin{array}{l}\text { Combined ALS and DAP data to provide } \\
\text { additional information on sub-stand level } \\
\text { growth projections }\end{array}$ \\
\hline Tompalski et al. 2019 & 2 & ALS, DAP & Slave Lake & $\begin{array}{l}\text { Used both ALS and DAP data to quantify } \\
\text { changes in forest structure in a highly disturbed } \\
\text { boreal mixedwood forest }\end{array}$ \\
\hline Tompalski et al. 2021 & 2 & ALS & Canada Wide & $\begin{array}{l}\text { A review of estimating changes in forest } \\
\text { attributes and enhancing growth projections } \\
\text { using ALS }\end{array}$ \\
\hline van Ewijk et al. 2019 & 2 & ALS & $\begin{array}{l}\text { Petawawa Research } \\
\text { Forest, Hearst Forest, } \\
\text { Haliburton Forest and } \\
\text { Wildlife Reserve }\end{array}$ & $\begin{array}{l}\text { Verification of predictions of inventory } \\
\text { attributes using texture and intensity metrics } \\
\text { and height-based ALS metrics }\end{array}$ \\
\hline van Ewijk et al. 2020 & 2 & ALS & $\begin{array}{l}\text { Hearst Forest, } \\
\text { Slave Lake }\end{array}$ & $\begin{array}{l}\text { Assessed transferability of forest attribute } \\
\text { models between two boreal forest sites }\end{array}$ \\
\hline van Lier et al. 2021 & 2 & ALS & $\begin{array}{l}\text { Harry's River } \\
\text { Watershed }\end{array}$ & $\begin{array}{l}\text { Assessment of the effect of scan angle on ALS } \\
\text { plot metrics and forest attribute predictions } \\
\text { using an ABA }\end{array}$ \\
\hline Wylie et al. 2019 & 2 & ALS & Hearst Forest & $\begin{array}{l}\text { Developed predictive models of mean stem age } \\
\text { and wood quality of black spruce-dominated } \\
\text { stands }\end{array}$ \\
\hline Yan and Shaker 2017 & 4 & Multispectral ALS & $\begin{array}{l}\text { Petawawa Research } \\
\text { Forest, Hearst Forest, } \\
\text { Haliburton Forest and } \\
\text { Wildlife Reserve }\end{array}$ & $\begin{array}{l}\text { Developed an approach to model the distortion } \\
\text { effects due to the range and the angle in MLS } \\
\text { data }\end{array}$ \\
\hline Yan et al. 2020 & 4 & Multispectral ALS & $\begin{array}{l}\text { Petawawa Research } \\
\text { Forest }\end{array}$ & $\begin{array}{l}\text { Assessment of radiometric corrections of } \\
\text { multispectral ALS for forest attribute prediction } \\
\text { accuracies }\end{array}$ \\
\hline
\end{tabular}

mortality of these stands, the error of the models describing growth was often higher than the growth itself. This important outcome allows forest managers to make more informed decisions when planning future data acquisitions and highlights the importance of understanding stand mortality when analyzing growth.

With regards to the second category, two approaches for integrating growth simulators with ALS data were tested within AWARE. The first study took the existing Albertabased growth and yield model (GYPSY; Huang et al. 2009) and used it to generate a library of growth trajectories. The library was then used in combination with ALS-derived celllevel stand attributes to identify a closest matching growth curve. The method used the same datasets as available at Slave Lake, and used an area-based approach (ABA) to predict $\mathrm{H}, \mathrm{BA}, \mathrm{V}$ and stand density $(\mathrm{N})$ for $\mathrm{T} 1$ and T2. Yield curves generated from GYPSY were then matched to $3 \mathrm{D}$ remote sensing observations for two scenarios. The first scenario used T1 estimates only, while the second combined T1 and $\mathrm{T} 2$ estimates, thereby increasing the number of data points used to identify the closest matching growth curve. Results indicated that the curves matched to two points in time yielded higher accuracy, and that the prediction error of the ABA estimates was the main driver of the curve matching accuracy. The reported relative root mean squared error (rRMSE) in forecasted attributes for $\mathrm{H}, \mathrm{BA}, \mathrm{V}$, and $\mathrm{N}$ were $13.2,44.6,50.4$ and $112.3 \%$, respectively.

A second study focused on integrating growth simulators with ALS data available for the Black Brook District in New Brunswick. Lamb et al. used a tree-list growth model to forecast forest inventory at a grid-cell level in spruce plantations. A library of tree lists was first created using plot data from a much larger area than the ALS acquisition. Tree lists were then assigned to every 20-m cell based on the smallest difference between six inventory attributes predicted with ALS and measured on plots. Assigned tree lists were then used to parametrize the growth model. To assess the accuracy, the authors used independent plot data and compared the annual increments derived using tree lists imputed by plot matching and tree lists measured in the field. Results showed 
a strong agreement (Pearson's $r$ between 0.75 and 0.86 ) between the increments, with relative RMSE between 12.8 and $49 \%$. Once tree lists were imputed for each grid cell, the Open Stand Model (OSM), which has been calibrated for the Acadian Forest Region, was applied in conjunction with commercial thinning eligibility rules to spatially plan annual commercial thinning over the next three years.

\section{Future directions}

The outcomes of forest growth-related studies within AWARE, as well as the research which has been conducted by others over this time, have highlighted the significant issues associated with estimating growth using point-cloud data and demonstrated that existing approaches are not yet ready for operationalization. The above cited papers all highlight the need for statistical rigor when analyzing multi-temporal point clouds.

Key outcomes from the AWARE project suggest additional research is required to develop guidance on when to apply direct or indirect approaches when analyzing growth at a grid-cell level, and on improving tree-to-tree matching over time when analyses are performed at the individual tree level. While the majority of studies at the cell level demonstrate that the direct approach is more accurate, others are contradictory. As multi-temporal 3D datasets become more prevalent across Canada, we recommend testing both direct and indirect approaches where possible to provide more consistent recommendations of what approach to apply under the range of forest and terrain conditions encountered. At the individual tree level, robust tree matching over time requires consistency (and improvement) in tree detection methods. While there are a large number of individual tree detection methods available, they have seldom been used to link multitemporal datasets or to assess individual tree-based growth. If forest companies wish to continue to develop and apply individual tree- based models, which is likely the case, given with an increasing interest in precision forestry applications like selective harvesting and thinning, then additional refinement of these methods is needed.

Finally, our work has highlighted additional research needed to identify the most appropriate ways to utilize pointcloud data to enhance the projections made by growth and yield models. As shown in research conducted at Slave Lake, methods for integrating point-cloud data are in the stages of development and are often specifically designed to work with an existing growth simulator or for a particular forested region. Research should focus on leveraging point-cloud information to better parametrize existing growth simulators, e.g., by improving estimates of site index or similar attributes that reduces the reliance upon a photo-interpreted or point-cloud predicted age. Lastly, ongoing research should focus on developing growth models driven entirely with point-cloud data. It is apparent, that across Canada, a wide variety of growth and yield models exist with limited ability for cross comparisons to be extrapolated country wide. Considering the cost associated with the development of growth simulators using traditional approaches, research should continue to incorporate remote sensing-based products to improve estimates from growth and yield models. Currently, growth functions often utilise complex modules to characterize mortality, ingrowth, competition, or account for various silvicultural activities (e.g., thinning, fertilization). Not all of these responses need to be explicitly integrated into ALS or DAP approaches, rather by comparing point clouds over time, insights could be gained into how stand dynamics or management activities impact the structure and thus growth of the stand.

Operationally-focused individual tree detection and species prediction

\section{The AWARE approach}

Throughout the five-years of AWARE, we have seen EFI's developed using ABA derived from LiDAR data become operational with many forestry organisations utilising this approach globally. However, there are operational decisions that would benefit from additional information about forest stands beyond statistical summaries within a gridded raster. Information on tree spacing and individual crown size are often required to support decision-making for precision silvicultural applications. In addition, understanding the species composition of stands has implications for timber value, health, and productivity decision-making. Alternatives to ABA are individual tree-based delineation (ITD) or segmentation (Chen et al. 2006; Koch et al. 2006). The accurate segmentation of individual trees to extract information on tree position and attributes, such as $\mathrm{H}$, diameter $(\mathrm{DBH}), \mathrm{V}$ and ultimately species, is a key data request from researchers and practitioners alike. ITD algorithms used with $3 \mathrm{D}$ remote sensing data can be generally divided into two types: algorithms based on a digital canopy height model (CHM) and those that utilise the original point cloud. The body of literature on individual tree segmentation is considerable, having been the focus of a number of comprehensive reviews and comparisons (Ke with the quality of the species identification being largely dependent on the success of the crown delineation (Yu et al. 2011). For approaches that utilise the CHM, the most common is to detect local maxima and then use an inverted watershed model to find the crown perimeter. While a variety of ITD algorithms have been developed and applied over a variety of forest types, it became apparent during the development of the AWARE project that many of these approaches were still within the research realm. These algorithms tend to be written in user-specific software, have only been applied over small areas and simply validated on a very small number of trees. In order for forestry companies to utilize these tree-based approaches to predict species in any operational way, new routines would need to be developed and programmed to allow for large-scale rollout and application. As a result, a new segmentation approach was developed through AWARE which allowed, (i) detailed information to be extracted from individual trees, including different types of structural and intensity metrics and, (ii) programing for extrapolation over large operational landbases. Issues such as tiling of LiDAR datasets, removing boundary effects from LiDAR tiles on crown predictions, and the development of robust geodatabases which can store ITD information are critical to the success of this new approach. A new crown detection and delineation approach, SEGMA, was developed based on marker detection and watershed. This approach first smooths the CHM to remove pits and then applies a Gaussian filter to remote variations caused by noise and edge effects. Next, local maxima are determined and a watershed 
algorithm using the reverse slope applied around each marker defines the outline of the tree crown. The detection of the local maxima is adapted to the local forest height such that sensitivity is strong for short canopies, and weaker for tall canopies. Subsequently, the shape of the crown serves then as a mask or cookie cutter to extract LiDAR returns within each crown, thereby defining and saving the point cloud for each tree in a single "micro-LAS" file. Importantly, SEGMA then computes a wide range of metrics for each micro-LAS file, and hence each tree. These include metrics related to height, variation in height (e.g., average slope between each crown return and the local maximum). Metrics based on return intensity are also extracted, on the assumption that different tree genera have different infrared reflective properties (such as broadleaf species generally having an intensity higher than conifers; Schreier et al. 1985). SEGMA was applied over the Black Brook District and calibrated using a total of 1500 trees which were matched in the field to the delineated crown layer. When applied over the entire estate, results indicated that there were over 290 million crowns segmented from ALS LiDAR data in the Black Brook District. A random forest model was then developed using the individual tree and crown metrics and models developed at genus and species levels. Results indicated that the most accurate model separated hardwoods from conifers (i.e., 93\% correct classification). Meanwhile, the overall accuracy was $49 \%$ for the 11 species in the study area. In most cases, misclassified trees were of a similar species in the context of forest management. In terms of metrics, the results of the random forest models indicated that the standard deviation of the first returns and all returns, the maximum intensity and the average intensity were the most important predictors of species over the area. Among the structural metrics, the slope of the crown was the most important for delineating species (Perron 2018).

Building on the initial development work of SEGMA, the tool was then applied at the Petawawa Research Forest (PRF) to investigate if recent improvements in LiDAR technology could improve previous segmentation and classification results. Two advances in LiDAR-based technology emerged during AWARE. Firstly, multispectral ALS was introduced with three spectral wavelength LiDAR systems tuned to the green, near-infrared and short wave infrared regions of the spectrum, thereby allowing additional intensity-based metrics to be derived and compared to monospectral ALS systems used previously. Secondly ALS point density is a function of the flight altitude and the flight speed for a given pulse repetition frequency, resulting in a direct relationship between the cost $\left(\$ / \mathrm{km}^{2}\right)$ of acquisition and the point density (points $/ \mathrm{m}^{2}$ ). Researchers started to explore photon counting instruments designed to cover larger areas for the same cost in the 1990s. Single Photon Lidar (SPL) systems address the perceived cost shortcomings of traditional linear ALS systems by facilitating a higher point density for a given flight altitude or by achieving acceptable point densities while flying at a higher altitude, permitting greater coverage. As a result, we also examined if additional features provided by multispectral ALS or increased point density provided by SPL are important when undertaking ITD and species assessment. Three different ALS datasets formed the comparison: monospectral ALS data (Riegl 680i, $1064 \mathrm{~nm}$ ) acquired in
2012 (ALS12), multispectral ALS data (Optech Titan, 532, 1064 and $1550 \mathrm{~nm}$ ) acquired in 2016 (MSL16), and SPL data (Leica SPL100, $532 \mathrm{~nm}$ ) acquired in 2018 (SPL18). Reference training crowns were sampled and identified using SEGMA on the 2012 monospectral ALS dataset and matched to field crown datasets compiled by Ontario Ministry of Natural Resources photo interpreters and AWARE researchers. Models based on SPL data exhibited an overall slightly lower accuracy than conventional ALS systems. Additionally, the ratio of $1^{\text {st }}$ to $2^{\text {nd }}$ returns, which has been shown to be highly important for species assessment, were not significant predictors in the SPL models due to differences in the technology, which also may explain its lower performance.

Not surprisingly, high stand density of hardwood-dominated forests, such as at PRF, reduces classification performance when compared to more open stands. ITC delineation (and subsequent identification of training crowns in the field) in this type of environment is challenging and can introduce errors of omission and commission when identifying tree crowns in these conditions. The relatively low number of training samples per class (30 crowns for some classes) at this granularity level is also a constraint to classification accuracy. The hardwood/softwood, functional group and four species classification accuracies, however, are encouraging (accuracies $>70 \%$ ) across all three datasets. The results indicate that the additional features provided by multispectral ALS are more beneficial to classification accuracy than the additional point density provided by SPL.

\section{Future directions}

The research undertaken within AWARE on ITD suggests that delineation of tree crowns remains a key area that requires improvement. Errors in delineation produce a suite of downstream effects that greatly affect individual tree-based assessments of species. In addition, poor delineations hampers the location of crowns in the field, making matching of ALS crown metrics to species problematic, given more advanced classifiers such as machine learning that random forests are extremely sensitive to noise in the datasets. Additional analysis of the species predictions also suggests, as others have in the past, that it is likely that accurate delineation of the entire crown may not be required, especially when using multiple wavelengths. Identification of crown tops and then portions of the crown surface, such as sunlit crown, in passive optical imagery remains a less complex approach which may produce similar accuracies. Results also suggest that in stands with many species, accurate prediction of all species is complex. However, if species are grouped into functional types, value, or form, the accuracies of the grouped species increase significantly. Key to the practical use of such models will be the identification of a spatial resolution for producing aggregate predictions that can both be accurate and scaled adequately to assist silvicultural decision-making. Rather than at the level of individual tree crowns, future work will focus on making forest composition predictions in $20 \mathrm{x}$ $20 \mathrm{~m}$ cells with compositional accuracy evaluated at scales broader than individual crowns, such as the scale of one hectare. Lastly, further development of species identification models will also require improved access to spatially explicit ground inventories of individual stems, especially when using more advanced machine learning classifiers, where 
training data is key. While 1500 individually identified crowns may be large in a remote sensing and field forestry context, it is a very small sample in the field of machine learning. Additional research is needed to investigate if we can augment training data with additional datasets or manual interpretations to increase the training set for these classifiers. The labelling, or annotation, of training crowns is also problematic when trying to match computer-generated crowns with crowns in the field. Mislabeled training crowns causes a loss of accuracy and predictive power when used these machine learning type approaches.

\section{Terrestrial LiDAR scanning in support of enhanced forest inventory \\ The AWARE approach}

ALS-based forest inventories rely on predictive models derived using reference data collected during field measurements. The accuracy of those models depends not only on the predictive power of point cloud-based independent variables (e.g., point-cloud metrics) but on the quality of this field reference data. While existing data collection protocols allow for creating detailed, cell-level, wall-to-wall predictions of forest stand attributes, those attributes are limited to those measured in the field. Individual tree attributes that describe stem or crown shape, number of whorls, branchiness, and crown base height for example, are much more difficult to measure in the field using conventional methods, yet they offer valuable insights into forest stand structure, wood quality, and can inform on the need for silvicultural activities such as thinning, and contribute to improved accuracy of ABA models.

Because of the extremely fine spatial details afforded by TLS point clouds, data collected over forest reference plots allows the capture of forest structure information with a high degree of detail, thus making it possible to characterize important individual tree attributes. Because of the finite range through a forest stand and occlusion, TLS is best suited to capture small areas (like forest plots), allowing for improved reference data which can then be used in large area modelling or to develop allometric models. One such example of how TLS data can be used to improve forest characterization performed with ALS point clouds was demonstrated in AWARE by, whereby TLS point clouds and an architectural model (L-Architect) were used to generate 3D "virtual" reference plots, which in turn were used to produce a library of tree models. Surrogate plots can then be created based on a standard set of tree attributes estimated with field measurements or ALS data. By creating a library of 3D scanned trees, the application of the TLS data is expanded beyond the plots where the data was collected and allows the creation of surrogate plots whenever the required individual tree data are available. Introducing surrogate plots into EFI workflows can improve prediction accuracy and allow for the estimation of fine-scale tree and forest structural attributes.

Another example of this enhanced ability to estimate forest attributes is demonstrated by Côté et al. (2020) who linked tree structural attribute models calibrated with TLS data to wood fibre attributes in Newfoundland. The structural attributes derived from $L$-Architect describing the crown geometry, branching structure, stem form, spatial competition and canopy material distribution were used to develop predictive models of wood fibre attributes. The percentage of variance explained for the wood fibre attributes ranged from $12-56 \%$ and $5-80 \%$ at tree- and plot-levels respectively, improving on models built only with inventory attributes by $23 \%$ (tree level) and 33\% (plot level). Better characterisation of forest structure using TLS and architectural modelling can thus lead to improved wood quality predictions in EFI.

Within AWARE, TLS data sets were acquired over a number of core sites. Novel methods were developed to automatically detect and characterize individual trees in the TLS point clouds. Among the individual tree attributes that can be derived from TLS data, DBH and stem diameter at different heights are often considered the most crucial. Ravaglia et al. (2019) compared three commonly used algorithms to estimate stem diameter: STEP (Snakes for Tuboid Extraction from Point cloud), Computree, and SimpleTree. The STEP algorithm, originally developed by Ravaglia et al. (2017), was specifically designed to estimate stem profile in natural forest environments. All three algorithms were tested in a number of forest ecosystems including balsam fir and black spruce dominated forests in Newfoundland and a white spruce plantation in Quebec. It was determined that the STEP algorithm was the most accurate, exhibiting mean stem diameter errors between $1.1 \mathrm{~cm}$ and $2.28 \mathrm{~cm}$.

Work from Crespo-Peremarch et al. (2020) also highlighted the use of TLS to support EFI development by assessing how ALS full waveform data can identify and estimate the density of understory. The study used datasets from the Harry's River Watershed in Newfoundland and from a second site in Spain. It demonstrated that TLS provides valuable estimates of complex tree and stand structural attributes which can then be used as reference data to calibrate the ALS full waveform data. The results from this work also confirmed that full waveform ALS data exceeds, by a large margin, the ability of discrete ALS to characterize vegetation understory.

\section{Future directions}

In AWARE, it was demonstrated that the integration of TLS into ALS-based EFIs is possible for several potential applications: (i) for direct estimation of complex structural attributes; (ii) in support of architecture modelling to generalize virtual inventory data; (iii) to increase availability of fine-scale explanatory variables in support of modelling e.g., wood fibre attributes; and, (iv) to validate complex model development. In addition, the development of new algorithms to extract key pieces of information from TLS point clouds can be adapted to new instruments providing high density point clouds like portable LiDAR or UAV-based LiDAR. These new approaches are now available within open source TLS data processing toolkits such as Computree. Despite these advances, ongoing model development and analysis are required to see TLS-based approaches becoming more commonplace as a means of collecting reference data for ABA models. We need to continue to examine the operational aspects of acquiring and processing ground-based point-cloud data, selecting the best methods to identify individual trees and estimate their attributes, and then input these attribute in area-based models. 


\section{Applications of LiDAR beyond forest inventory The AWARE approach}

While projects within AWARE were specifically designed to examine the role of 3D technologies to meet inventory needs through, for example, developing EFI's, there was a clear recognition that data acquisition costs constitute a considerable component of developing any LiDAR-based inventory system. In addition, the costs associated with the collection of field datasets and data processing for model development need to be considered. As a result, using inventory data to mainly focus and document wood production can be cost prohibitive, deterring forest managers from utilising these proven, yet perceived to be more expensive solutions.

One solution recognised in AWARE was to demonstrate how these $3 \mathrm{D}$ datasets acquired to support development of inventories could be used to characterize a range of other ecosystem goods and services that forest ecosystems provide beyond timber. This explicitly recognised that foresters need to make sustainable management decisions that focus on more than timber values alone and that $3 \mathrm{D}$ remote sensing data has a role to play in the estimation of these additional attributes. The maintenance and improvement of critical ecosystem components and processes like biodiversity, soils, water, and vegetation composition is fundamental to continued sustainable forest management and data on these nontimber ecosystem components enables quantification of forest ecological goods and services (EGS).

With respect to forest biodiversity within AWARE, linked avian species presence and abundance with LiDAR structural metrics over the Harry's River Watershed in Newfoundland. Results demonstrated LiDAR metrics alone produced significant models, but with a poorer fit than traditional field plot metrics. More conventional satellite-based spectral metrics alone were unable to produce significant models. The key finding was that models which combined LiDAR and environmental data had better goodness-of-fit than those with field data alone, suggesting that the integration of LiDAR data with other geospatial data can produce improved models for biodiversity assessment within an EFI context.

A second example involved the development of methodologies to estimate soil properties using advanced 3D remote sensing datasets. Although the concept of digital soil mapping, where soil attributes of interest are estimated using an array of digital surface layers such as climate, above ground vegetation condition and terrain characteristics such as slope, aspect and curvature, has been around for over two decades (McBratney et al. 2003; advances in remote sensing technologies warrant revisiting the topic with the addition of new high resolution predictors. The project direction was developed in part as a response to the success of the wet area mapping (WAM) initiative in Alberta which produced wall to wall coverages of depth to water table from LiDAR-derived DTMs. These DTMs had a variety of applications including accessibility and trafficability for forestry operations, especially in winter. In AWARE, Furze et al. (2017a), working at Black Brook District in New Brunswick, demonstrated the potential of leveraging multiple terrain data sets to improve the mapping of soil types and properties. Data fusion techniques were utilised to include LiDAR-derived topographic data and shuttle radar topography mission (SRTM) elevation layers to reduce eleva- tion biases and enable soil property estimation and multiscale mapping. Soil survey data from across New Brunswick were used to create an aspatial soils database, develop pedotransfer models and predict soil profile descriptions at changing depths. These data were combined with terrain derivatives and superficial geology to model and map soil properties across the province. Layers predicting a range of attributes including drainage, texture (sand, silt, and clay), depth of solum and A, B horizons, coarse fragment content, soil organic matter content, and bulk density.

Another important aspect of enhancing forest inventories relates to the expansion of uses for ecological land classification schemes. Previous studies have demonstrated the potential for predicting mean wood density and fibre length of key species such as black spruce based on polygon-level attributes such as ecosite or moisture regime (Pokharel et al. 2014; Townshend et al. 2015). However, such models were restricted to application in young stands (e.g., $\leq 50$ years) because fibre attributes in individual trees are driven by developmental changes through time (Lachenbruch et al. 2011), and site differences in wood quality can be confounded by age. An AWARE project focused on the use of LiDAR-derived variables in a $k$ nearest neighbour $(\mathrm{kNN})$ approach to predict mean stem age in black spruce-dominated stands of the boreal forest of northeastern Ontario, and then refined spatial wood density models for black spruce to include age and ecosite as predictors (Wylie et al. 2019). The pairing of LiDAR and ecosite data in this process produced estimates of wood density of comparable accuracy to previous approaches, while expanding the range of conditions over which they can be applied to stands dominated by trees up to 120 years old.

Lastly, a key area of interest for forest managers across Canada is leveraging remote sensing data to develop improved methods to understand changes in forest health and condition. In eastern Canada, spruce budworm (Choristoneura fumiferana (Clem.), Lepidoptera: Tortricidae) is a native defoliating insect with an important disturbance role in the boreal forests. AWARE supported a number of projects focused on this issue. At the ground level, an AWARE project evaluated the use of hemispherical crown canopy images to quantify annual spruce budworm defoliation in Quebec. Images were acquired before and after defoliation events and compared to identify differences. Changes in canopy gap fraction derived from the images were then used to assess drivers of canopy change including insecticide spraying and proportion of balsam fir basal area. Results suggested that digital ground-based canopy imagery offers a feasible, non-destructive, and objective method to assess canopy foliage changes caused by spruce budworm defoliation. Linking field measured observations of stages of decline to LiDAR point clouds can be difficult. These ground surveys were also linked to satellite hyperspectral observations to predict defoliation classes over larger areas, with accuracies significantly higher than for aerial survey defoliation (Donovan et al. 2021). Conventional single wavelength LiDAR data are typically poor at detecting small changes in forest condition. Lack of information on pigment absorption or leaf structure returned by the laser pulse limits the ability of these data to convey change. As a result, changes in chlorophyll or other pigments are often unable to be easily extracted from a 
LiDAR point-cloud, limiting its application to assess early states of forest health and decline. In contrast, the development of point clouds from DAP, which provide spectral information from aerial imagery, offers potential to generate metrics describing broad pigment and leaf structure information. This is especially the case when using near infrared aerial imagery, which has been shown to be highly useful in detecting low levels of foliage damage and decay in response to insects and pathogens.

Another project was undertaken at the Gordon Cousins Forest, south of Kapuskasing, Ontario. The project assessed the ability of high spatial resolution DAP point clouds to predict cumulative defoliation in spruce budworm host stands. A partial least squares modelling framework was adopted to determine whether cumulative defoliation was detectable using DAP-derived structural metrics, as well as to outline the relative effectiveness of spectral (e.g., mean normalised difference vegetation index) versus structural (e.g., $90^{\text {th }}$ percentile of height) metrics, or their combination, for estimating cumulative defoliation. Results indicated that spectral metrics were the most effective for estimating cumulative defoliation $\left(\mathrm{R}^{2}=0.79\right)$, while structural metrics were less effective $\left(\mathrm{R}^{2}=0.49\right)$. Metrics characterizing variance of the spectral values were found to be the most important predictors. While spectral metrics were more capable of modelling cumulative defoliation, structural metrics were more effective for estimating standard inventory attributes like volume and basal area. These results suggest that the provision of both structural and spectral metrics from a single conventionally flown aerial survey has potential to enhance defoliation monitoring and forest inventory modelling.

\section{Future directions}

The optimal use of LiDAR data within forestry organizations is critical to ensure its cost effectiveness. The projects within AWARE demonstrate that statistical characterizations of vegetation and terrain are highly valuable for characterizing and monitoring environmental conditions. The potential of LiDAR data to provide added value to digital soil mapping, water movement, biodiversity and forest health is highlighted in Goodbody et al. (2020). They argue that the additional benefits that LiDAR data can provide to EFI can be summarized into four key points. First, LiDAR-derived ecological attributes should be continuous in nature, of defined levels of accuracy, and spatially explicit. Ecological attributes with these characteristics will benefit management outcomes. The use of LiDAR supports the continued creation of ecological attributes, enabling them to be multi-use and adaptable. There is an explicit recognition that data within inventory systems can be leveraged and supplemented to provide information about ecological goods and services to serve more than just the harvest function. Second, consultation and thought should be given to defining and standardizing LiDAR acquisition parameters like point density, overlap, and scan angle to ensure they meet a variety of needs, given that specifications for digital terrain model creation may differ from those for timber volume estimation. Third, integration of LiDAR-derived products into available processing workflows and models needs to be prioritized. To ensure data are adaptable and multi-use, a number of standard products can be derived from LiDAR data. For example, generating a
DTM is a critical first step for estimating water and soil attributes. A CHM is also a relatively standard LiDAR product that can be used for measuring tree and stand height with direct links to forest structure and potentially animal habitat. Lastly, forest managers must consider how to best integrate LiDAR-derived ecosystem service indicators into inventories to ensure all users of the products are familiar with potential advantages and disadvantages of these types of data in ecosystem predictions. Integration requires software systems that are flexible in the way they process data to produce desired outcomes and in combination with data storage and management systems that are able to easily utilize and summarize raster based datasets.

\section{AWARE outcomes and lessons learned Data and tools}

The AWARE project leaves a number of legacies that will continue to support the Canadian forest industry through research and development (Table 2). The first of these is a series of data sets for the core sites across the country, many of which can be used openly and free of charge by other researchers. Two key data sets that were acquired include the 2016 multispectral LIDAR data from the Teledyne Optech TITAN system acquired over the PRF in Ontario, and a high density, full waveform LiDAR dataset, acquired over the Harry's River Watershed in Newfoundland. The PRF acquisition complements the substantial existing database of imagery and plot data at this 100-year-old research forest that was recently established in 2019 as a remote sensing supersite and innovation hub by the Canadian Wood Fibre Centre (White et al. 2019). In addition to remote sensing data acquisitions, field datasets were also compiled for these areas and are in many cases available with the remote sensing data to aid interpretation and analysis.

A second legacy of the AWARE project is the production of software and packages which can be used by researchers and practitioners alike for LiDAR processing. The first of these packages is lidR, a freely available and open source toolkit which allows for manipulation of LiDAR data to produce a wide range of products. Written in the open source $R$ programming language allows the code to be viewed, interrogated and edited, and includes a wide variety of tools to allow users to predict both individual tree and area-based lidR outcomes. In addition, the highly flexible programming language allows attributes to be derived from $3 \mathrm{D}$ point clouds at the point, tree, or grid scales. Such flexibility, coupled with the fact that it serves as a repository for numerous routines and algorithms published in the literature, likely explains the rapid adoption of this $\mathrm{R}$ package, especially among users in the scientific community. LidR is available at the CRAN site listed at the end of this paper. A second software output from AWARE is the aforementioned SEGMA program. This program was specifically designed by AWARE researchers to allow individual tree delineation across large areas in an operational mode. Many existing individual tree delineation programs have been plagued with memory issues when applied over large areas. A key benefit of the SEGMA architecture is the ability to undertake individual tree level extractions over very large LiDAR datasets in serial or parallel mode. Once individual trees have been extracted, SEGMA also produces a wide number of attributes at the individual 
tree level that can then be used to inform the estimation of other tree level attributes such as height, volume, crown characteristics and species. The SEGMA series of programs is also available free of charge to users interested in applying individual tree- based approaches over large areas. Additional $\mathrm{R}$ packages for extending LiDAR observations over larger areas, using satellite data (such as FOSTER, Forest Structure Extrapolation with R) were also developed (Quinnec et al. 2021).

\section{Benefits}

The AWARE project was strategically designed to bring together university academics, researchers and managers from private industry and government agencies to address relevant research questions around the assessment of $3 \mathrm{D}$ remote sensing technologies for forest inventories. To facilitate effective collaboration throughout AWARE, a number of organizational structures were put in place during project planning and implemented through the five-year project. For each research project undertaken by an $\mathrm{MSc}$ or $\mathrm{PhD}$ graduate student, supervisory committees were encouraged to include membership from either an industry or government representative or both. Within AWARE this was often achieved with many students benefiting from the insights provided by companies and government researchers on their project. This collaboration resulted in a number of tangible benefits, including the ability of industry collaborators to ensure research outcomes were more closely aligned with the industry needs, as well as helping increase awareness of other approaches and methodologies that government and industry researchers may be interested in seeing applied. Some successful examples include the development of high spatial resolution soil properties which were able to be integrated into forest inventory systems within JD Irving Limited in New Brunswick, investigation of new imputation of LiDAR attributes over larger spatial areas to allow broad scale forest inventory assessments in Newfoundland, and the use of new technologies such as DAP to inform forest inventory programs across Canada.

A second tangible benefit of the AWARE project was the development and promotion of core sites across the country to focus research activity. By defining these core sites with industry at the commencement of the project allowed research activities to be focused at common sites, thereby benefiting companies, government and students with respect to common data sets, field trips and alignment of research questions. Meanwhile, a partnership with Optech Inc. allowed for the deployment of the Titan Multispectral LiDAR system to the PRF to test the utility of multispectral LiDAR data for forest inventory applications.

A third benefit of the AWARE project was the continual engagement of industry and government with academia through regular core site working group meetings, student forums which allowed students to present their new results in a peer-to-peer framework, as well as annual general meetings which allowed students to present their results to government and industry researchers in a friendly and constructive manner. To ensure methods and outcomes aligned with best practice and industry needs, regular communication through teleconferences and in-person meetings fostered a strong sense of community, which allowed research outcomes to be more strategically applied than if students and academics were working on their own. The AWARE project hosted four annual general meetings each attended by students, faculty members, government researchers and managers, and industry representatives. The meetings were held in different locations, often focused on core sites, allowing all participants to learn first-hand of the industry research needs, as well as to experience the unique forestry conditions. AWARE therefore supported a large number of MSc and $\mathrm{PhD}$ theses, with a small number still in progress, and a large number of peerreviewed research papers (Table 3), with many more conference proceedings and poster presentations. In addition, by investing in research groups across the seven universities, many other international visiting students, academics, as well as undergraduate students worked with AWARE students and researchers and benefited from the AWARE datasets and developed approaches. An e-lecture series highlighting key outcomes of the research by AWARE researchers was also hosted by the CIF-IFC national electronic lectures platform (Table 2). By fostering collaboration within the broader community, AWARE facilitated other research opportunities that were of direct benefit to stakeholders. In particular, engagement with forest inventory experts within provincial governments facilitated investigations into research questions of common interest.

Finally, by encouraging students to work closely with industry and government researchers, opportunities for employment and network development in the future has occurred with a number of AWARE graduates now employed by, or continuing to collaborate with, AWARE industrial or government partners.

\section{Implementation challenges}

While most collaboration initiatives were deemed successful throughout AWARE, a number of expectations were not fully realized.

\section{Industry uptake}

There were many examples of student research projects which aligned with industrial needs outlined by the company throughout the project. However, in some cases, proposed projects did not explicitly align with research needs or research needs evolved throughout the five years of the project, making the results less relevant than hoped for. This can be attributed to a variety of reasons. One important challenge was meeting both the expectations of the industry for rapid, practical answers and the requirements of academic institutions for producing significant scientific advances and new knowledge. In many cases, overcoming this challenge required more than the development of a common understanding of each other's reality. It required clear management of expectations on both sides to ensure that research outcomes were timely, while allowing for individual project development and intellectual growth by the student. Often a research outcome for a student or academic is a peerreviewed paper, whereas for industry or government it is tool or product ready for operational application. The time and resources required to bridge that gap can be considerable. We recognize that industry uptake could have been greatly facilitated by the inclusion of technology transfer firms and consultants in such large research partnerships who are often 
well versed in taking research outputs and applying them operationally. We recognize there may have been a missing link in AWARE in this respect.

Changing priorities: Related to the previous point is the issue of adapting to the rapid evolution of priorities in the forest industry. Research needs within an industry are often driven by a combination of short-term market needs as well as longer term research and development missions. Sometimes projects defined at the beginning of AWARE were no longer aligned with industry needs towards the end of the five-year project. As a result, research outcomes from students may not have directly met industry needs at their completion. One key recommendation from AWARE when developing large multi-university, multi-faceted projects is to encourage flexibility in project design to allow project objectives to evolve over the lifetime of the project, or to allow new and emerging questions to be identified.

Operational readiness: Industrial partners, in many cases, anticipate that research outcomes should directly inform management and operational decision-making and ideally should directly feed into operational realities. To do so requires that research approaches and methodologies be tested and validated. If software is developed, it needs to be well-documented, robust, and ready to be implemented. Over the past decade in Canada, we have seen the development of a number of intern-focused funding sources, such as MITACS, which complement the more conventional grantfocused NSERC research-based funding. When developing new research partnerships, internships could be explicitly designed to generate research outcomes that are more directly linked to the companies themselves, which would then allow students at the end of their program to work directly with industry to ensure implementation of the results. Ultimately, we believe the highly qualified personnel trained through the AWARE project, and eventually employed by industry, government and universities, will be the best catalyst for innovation in Canadian forest remote sensing over the coming decade.

\section{Recommendations}

- In a technological field such as remote sensing, five years is a long time. New research questions emerge as technology evolves, requiring flexibility in project design in order to develop new questions and engage new partners. Such flexibility is important if the research is to remain relevant and timely. The funding mechanism of AWARE did not necessarily allow for this level of flexibility. As a result, it is our recommendation that flexibility be built into the project design - allowing for new questions to be incorporated into the project as it evolves.

- Technology transfer and knowledge exchange is a critical element for engaging with regulators and industry stakeholders and is something that needs to be integral to both individual projects, as well as large interdisciplinary projects as a whole. It also requires substantial effort, time and resources to complete. Scientific publications are essential communications, but non-scientific syntheses are also critical to engage with non-academic partners (e.g., White et al. 2013, 2017). Time and resources must be allocated to these outcomes. With a project such as AWARE that involves new technologies and approaches, technology transfer activities really start when the project starts, particularly in engaging with industrial partners. This technology transfer is then an active component throughout the lifecycle of the project.

- Open data sharing is becoming increasingly important for scientific research and uptake of new technologies by industry. Establishment of an open data sharing portal allows for transparency, leverages investments in primary data collection, and enables engagement with industry stakeholders

- Contributions from industrial partners took the form of funding as well as in-kind support. The latter can be challenging for industry to sustain over a project's 5-year lifecycle, with different companies having different capacities for engagement. More flexibility in defining the in-kind contribution is needed to allow industry to derive the most benefit from its involvement in the project.

\section{Conclusions}

The five-year AWARE project facilitated unique collaborations among university, industry and government. While conventionally strong collaborative relationships have been developed between a single research team and an individual company, AWARE specifically recognised the combined benefits of linking teams of researchers and industry representatives together, with the hope that collectively the research results would be greater than if individual teams had developed the research outcomes alone. The project generated a range of deliverables addressing forestry needs at the individual tree to national scales, while providing exceptional training opportunities for students at a range of levels. As a result, we are confident the legacy of AWARE will be of high quality science, with strong evidence that the forest industry can identify focused research needs, and that both governments and universities can collaborate with industry to address these needs, leading to a more competitive Canadian forest sector with improved information outcomes to support sustainable forest management decision-making.

\section{Acknowledgements}

This research was funded by the AWARE (Assessment of Wood Attributes using Remote Sensing) Natural Sciences and Engineering Research Council of Canada Collaborative Research and Development grant. Industrial support was received from: FP-Innovations, West Fraser, Corner Brook Pulp and Paper Limited, Ryam Forest Management (formally Tembec), and JD Irving Limited. Additional contributions were received from Columbia Forest Products and Hearst Forest Management. Significant in-kind support was provided by the Canadian Wood Fibre Centre (CWFC), Canadian Forest Service, the Northern Hardwood Institute and Provincial Forestry Ministries. The universities involved in AWARE were the University of British Columbia, Laval University, University of New Brunswick, Sherbrooke University, Queens University, l' Université du Québec á Montréal, University of Toronto, Nipissing University and Laval University.

In addition to the strong support from all of these organisations, the AWARE research team specifically acknowledges critical support from Doug Pitt, George Bruemmer, Denis Ouellet and Denis Cormier who were instrumental in the initial support and in tireless efforts building support for 
AWARE in the CWFC and FPInnovations. Two international reviewers (Dr Ross Nelson, NASA (retired) and Prof Sorin Popescu (Texas A \& M University) attended all annual general meetings and provided key feedback on research and AWARE projects. We thank them for their tireless support and enthusiasm for AWARE. We acknowledge the research team à l' Université du Québec á Montréal for the operationalization of SEGMA. We also acknowledge the critical logistical and organisation support (and huge enthusiasm for the project and its students) by the AWARE program administrators Curtis Marr and Gladys Tecson. It could not have happened without you.

\section{References}

Bolton, D.K., N.C. Coops, T. Hermosilla, M.A. Wulder and J. C. White. 2018. Evidence of vegetation greening at alpine treeline ecotones: Three decades of Landsat spectral trends informed by LiDARderived vertical structure. Environ. Res. Lett. 13(8): 084022. doi:10.1088/1748-9326/aad5d2.

Bolton, D.K., P. Tompalski, N.C. Coops, J.C. White, M.A. Wulder, T. Hermosilla, M. Queinnec, J.E. Luther, O.R. van Lier, R.A. Fournier, M. Woods, P.M. Treitz, K.Y.van Ewijk, G. Graham and L. Quist. 2020. Optimizing Landsat time series length for regional mapping of LiDAR-derived forest structure. Remote Sens. Environ. 239: 111645. doi:10.1016/j.rse.2020.111645.
Briggs, D. 2010. Enhancing forest value productivity through fiber quality. J. For. 108(4): 174-182. doi:10.1093/jof/108.4.174.

Budei, B.C. and B. St-Onge. 2018. Variability of multispectral LiDAR 3D and intensity features with individual tree height and its Influence on needleleaf tree species identification. Can. J. Remote Sens. 44(4): 263-286. doi:10.1080/07038992.2018.1478724.

Budei, B.C., B. St-Onge, C. Hopkinson and F.A. Audet. 2018. Identifying the genus or species of individual trees using a threewavelength airborne lidar system. Remote Sens. Environ. 204: 632647.doi:10.1016/j.rse.2017.09.037.

Cao, L., N.C. Coops, J.L. Innes, S.R.J. Sheppard, L. Fu, H. Ruan and G. She. 2016. Estimation of forest biomass dynamics in subtropical forests using multi-temporal airborne LiDAR data. Remote Sens.Environ. 178: 158-171. doi:10.1016/j.rse.2016.03.012.

Chen, Q., D. Baldocchi, P. Gong and M. Kelly. 2006. Isolating individual trees in a savanna woodland using small footprint LiDAR data. Photogram. Eng. Rem. Sens. 72(8): 923-932

Coops, N.C. and M.A. Wulder. 2019. Breaking the habit(at). Trends Ecol. Evol. 34(7): 585-587. doi:10.1016/j.tree.2019.04.013.

Coops, N.C. P. Tompalski, T.R.H Goodbody, M. Queinnec, J.E. Luther, D.K. Bolton, J.C, White, M.A. Wulder, O.R. van Lier, T. Hermosilla 2021. Extrapolating LiDAR-derived estimates of forest attributes over space and time: A review of approaches and future trends. Rem. Sens. Envion. (in review).

Côté, J.-F., R.A. Fournier, J.E. Luther and O.R. van Lier. 2018. Fine-scale three-dimensional modeling of boreal forest plots to improve forest characterization with remote sensing. Remote Sens. Environ. 219: 99-114. doi:10.1016/j.rse.2018.09.026.

Côté, J-F., J.E. Luther, P. Lenz, R.A. Fournier and O.R. van Lier. 2020. Assessing the impact of finescale structure on predicting wood fibre attributes of boreal conifer trees and forest plots. Forest Ecol. Manage. 479: 118624. doi:10.1016/j.foreco.2020.118624.

Crespo-Peremarch, P., R.A. Fournier, V.-T. Nguyen, L.A. Ruiz and O.R. van Lier. 2020. Comparative detection of the vertical distribution of forest components with full-waveform, discrete airborne and discrete terrestrial laser scanning data. Forest Ecol. Manage. 473: 118268. doi:10.1016/j.foreco.2020.118268.

Degnan, J.J. 2002. Photon-counting multikilohertz microlaser altimeters for airborne and spaceborne topographic measurements. J. Geodyn. 34(3-4): 503-549. doi:10.1016/S0264-3707(02)00045-5.

Donovan, S.D., D.A. MacLean, J.A. Kershaw and M.B. Lavigne. 2018. Quantification of forest canopy changes caused by spruce budworm defoliation using digital hemispherical imagery. Agric. For. Meteorol. 262: 89-99. doi:10.1016/j.agrformet.2018.07.006.

Donovan, S.D., D.A. MacLean, Y. Zhang, M.B. Lavigne and J.A. Kershaw. 2021. Evaluating annual spruce budworm defoliation using change detection of vegetation indices calculated from satellite hyperspectral imagery. Remote Sens. Envion. 253: 112204 doi.org/10.1016/j.rse.2020.112204

Duncanson, L. and R. Dubayah. 2018. Monitoring individual treebased change with airborne LiDAR. Ecol. Evol. 8(10): 5079-5089. doi:10.1002/ece3.4075.

Fernandez-Diaz, J., W. Carter, C. Glennie, R. Shrestha, Z. Pan, N. Ekhtari, A. Singhania, D. Hauser and M. Sartori. 2016. Capability assessment and performance metrics for the Titan Multispectral Mapping LiDAR. Remote Sens. 8(11): 936. doi:10.3390/rs8110936.

Fridman, J., S. Holm, M. Nilsson, P. Nilsson, A.H. Ringvall and G. Ståhl. 2014. Adapting National Forest Inventories to changing requirements - The case of the Swedish National Forest Inventory at the turn of the $20^{\text {th }}$ century. Silva Fenn. 48(3):1-29. doi: 10.14214/sf.1095.

Frizzle, C. R.A. Fournier, M. Trudel and J.E. Luther. 2021. Using the soil and water assessment tool to develop a LiDAR-based index of the erosion regulation ecosystem service. J. Hydrol. 595. doi:10.1016/j.jhydrol.2021.126009. 
Furze, S., M. Castonguay, J. Ogilvie, M. Nasr, P. Cormier, R. Gagnon, G. Adams and P.A. Arp. 2017a. Assessing soil-related black spruce and white spruce plantation productivity. Open J. For. 7(02): 209-227. doi:10.4236/ojf.2017.72013.

Furze, S., J. Ogilvie and P.A. Arp. 2017b. Fusing digital elevation models to improve hydrological interpretations. J. Geogr. Inf. Syst. 9(05): 558-575. doi:10.4236/jgis.2017.95035.

Genuer, R., J.M. Poggi and C. Tuleau-Malot. 2015. VSURF: An R package for variable selection using random forests. The $\mathrm{R}$ Journal. 7(2): 19-33. doi:10.32614/rj-2015-018.

Gillis, M.D. 2001. Canada's National Forest Inventory (Responding to current information needs). Environ. Monit. Assess. 67: 121-129 doi:10.1023/A:1006405820244

Goodbody, T.R.H., N.C. Coops and J.C. White. 2019. Digital aerial photogrammetry for updating areabased forest inventories: A review of opportunities, challenges and future directions. Curr. For. Reports. 5: 55-75. doi:10.1007/s40725-019-00087-2.

Goodbody, T.R.H., N.C. Coops, P. Tompalski, P. Crawford and K.J. Day. 2016. Updating residual stem volume estimates using ALS- and UAV-acquired stereo-photogrammetric point clouds. Int. J. Remote Sens. 38(8-10): 2938-2953. doi:10.1080/01431161.2016 .1219425 .

Goodbody, T.R.H., N.C. Coops, T. Hermosilla, P. Tompalski, G. Mccartney and D.A. Maclean. 2018a. Digital aerial photogrammetry for assessing cumulative spruce budworm defoliation and enhancing forest inventories at a landscape-level. ISPRS J. Photogramm. Remote Sens. 142: 1-11. doi:10.1016/j.isprsjprs 2018.05.012.

Goodbody, T.R.H., N.C. Coops, T. Hermosilla, P. Tompalski and G. Pelletier. 2018b. Vegetation phenology driving error variation in digital aerial photogrammetrically derived Terrain Models. Remote Sens. 10(10): 1554. doi:10.3390/rs10101554.

Goodbody, T.R.H., P. Tompalski, N.C. Coops, C. Hopkinson, P. Treitz and K. van Ewijk. 2020. Forest inventory and diversity attribute modelling using structural and intensity metrics from multispectral airborne laser scanning data. Remote Sens. 12(13): 2109. doi:10.3390/rs12132109.

Goodbody, T.R.H., N.C.. Coops, J.E. Luther, P. Tompalski, C. Mulverhill, C. Frizzle, R. Fournier, S. Furze and S. Herniman. (2021). Airborne laser scanning for quantifying criteria and indicators of sustainable forest management in Canada. Can. J. Forest Res. (in press).

Guo, X., N.C. Coops, P. Tompalski, S.E. Nielsen, C.W. Bater and J. John Stadt. 2017. Regional mapping of vegetation structure for biodiversity monitoring using airborne LiDAR data. Ecol. Inform. 38: 50-61. doi:10.1016/j.ecoinf.2017.01.005.

Herniman, S., N.C. Coops, K. Martin, P. Thomas, J.E. Luther and O.R. van Lier. 2020. Modelling avian habitat suitability in boreal forest using structural and spectral remote sensing data. Remote Sens. Appl. Soc. Environ. 19: 100344. doi:10.1016/j.rsase.2020 .100344.

Huang, S., S. X. Meng and Y. Yang. 2009. A growth and yield projection system (GYPSY) for natural and post-harvest stands in Alberta. [online]. For. Div. Alberta Sustain. Resour. Dev. Tech. Rep. T/216, 1-22. Avaliable from https://open.alberta.ca/dataset/ 2a58d86b-b011-477e-bbeb-d9a6c67477bd

Ke, Y. and L.J. Quackenbush. 2011. A review of methods for automatic individual tree-crown detection and delineation from passive remote sensing. Int. J. Remote Sens. 32(17): 4725-4747. doi:10.1080/01431161.2010.494184.

Koch, B., U. Heyder and H. Weinacker. 2006. Detection of individual tree crowns in airborne LiDAR data. Photo. Eng. Rem. Sens. 72(4):357-363

Lagacherie, P. and A.B. McBratney. 2006. Chapter 1: Spatial Soil Information Systems and Spatial Soil Inference Systems: Perspectives for Digital Soil Mapping. Dev. Soil Sci. 31: 3-22. doi:10.1016/S0166-2481(06)31001-X.
Lamb, S.M., D.A. MacLean, C.R. Hennigar and D.G. Pitt. 2017. Imputing tree lists for New Brunswick spruce plantations through nearest-neighbor matching of airborne laser scan and inventory plot data. Can. J. Remote Sens. 43(3): 269-285. doi:10.1080/ 07038992.2017.1324288.

Lamb, S.M., D.A. MacLean, C.R. Hennigar and D.G. Pitt. 2018. Forecasting forest inventory using imputed tree lists for LiDAR grid cells and a tree-list growth model. Forests 9: 1-18. doi:10.3390/ f9040167.

Li, Q., J. Degnan, T. Barrett and J. Shan. 2016. First evaluation on single photon-sensitive LiDAR data. Photogramm. Eng. Remote Sens. 82: 455-463. doi:10.14358/pers.82.7.455.

Lachenbruch, B., J.R. Moore and R. Evans. 2011. Radial variation in wood structure and function in woody plants, and hypotheses for its occurrence in size- and age-related changes in tree structure and function. Meinzer, F.C., Lachenbruch, B. (Eds.). Springer: New York, NY, USA.

Leckie, D.G. and M.D. Gillis. 1995. Forest inventory in Canada with emphasis on map production. For. Chron. 71(1): 74-88.

Luther, J.E., R.A. Fournier, O.R. van Lier and M. Bujold. 2019. Extending ALS-based mapping of forest attributes with medium resolution satellite and environmental data. Remote Sens. 11(9): 1092. doi:10.3390/rs11091092.

Magnussen, S., G. Stinson and P. Boudewyn. 2017. Updating Canada's National Forest Inventory with multiple imputations of missing contemporary data. For. Chron. 93(03): 241-245. doi: 10.5558/tfc2017-030

Marczak, P.T., K.Y. van Ewijk, P.M. Treitz, N.A. Scott and D.C.E. Robinson. 2020. Predicting carbon accumulation in temperate forests of Ontario, Canada using a LiDAR-initialized growth-andyield model. Remote Sens. 12(1): 201. doi:10.3390/rs12010201.

Mauro, F., M. Ritchie, B. Wing, B. Frank, V. Monleon, H. Temesgen and A. Hudak. 2019. Estimation of changes of forest structural attributes at three different spatial aggregation levels in Northern California using multitemporal LiDAR. Remote Sens. 11: 923. doi:10.3390/rs11080923.

McBratney, A.B., M.L. Mendonça Santos and B. Minasny. 2003. On digital soil mapping. Geoderma. 117(1-2): 3-52. doi:10.1016/ S0016-7061(03)00223-4.

McRoberts, R.E., O.M. Bollandsås and E. Næsset. 2014. Modeling and estimating change. In: Forestry Applications of Airborne Laser Scanning Concepts and Case Studies. 27: 293-313. doi:10.1007/97894-017-8663-8_15.

McRoberts, R.E., E. Næsset, T. Gobakken and O.M. Bollandsås. 2015. Indirect and direct estimation of forest biomass change using forest inventory and airborne laser scanning data. Remote Sens. Environ. 164: 36-42. doi:10.1016/j.rse.2015.02.018.

Mulverhill, C., N.C. Coops, P. Tompalski and C.W. Bater. 2020. Digital terrestrial photogrammetry to enhance field-based forest inventory across stand conditions. Can. J. Remote Sens. 46(5): 622639. doi:10.1080/07038992.2020.1831376

Mulverhill, C., N.C. Coops, P. Tompalski, C.W. Bater and A.R. Dick. 2019a. The utility of terrestrial photogrammetry for assessment of tree volume and taper in boreal mixedwood forests. Ann. For. Sci. 76(2): 83. doi:10.1007/s13595-019-0852-9.

Mulverhill, C., N.C. Coops, J.C. White, P. Tompalski and P.L. Marshall. 2019b. Structural development following stand-replacing disturbance in a boreal mixedwood forest. For. Ecol. Manage. 453: 117586. doi:10.1016/j.foreco.2019.117586.

Mulverhill, C., N.C. Coops, J. White, P. Tompalski, P. Marshall and T. Bailey. 2018. Enhancing the estimation of stem-size distributions for unimodal and bimodal stands in a boreal mixedwood forest with airborne laser scanning data. Forests 9(2): 95. doi:10.3390/f9020095. 
Næsset, E. and T. Gobakken. 2005. Estimating forest growth using canopy metrics derived from airborne laser scanner data. Remote Sens. Environ. 96(3-4): 453-465. doi:10.1016/j.rse.2005.04.001.

Noordermeer, L., R. Økseter, H. Ole Ørka, T. Gobakken, E. Næsset and O.M. Bollandsås. 2019. Classifications of forest change by using bitemporal airborne laser scanner data. Remote Sens. 11(18): 2145. doi:10.3390/rs11182145.

Nuijten, R.J.G., N.C. Coops, T.R.H. Goodbody and G. Pelletier. 2019. Examining the multi-seasonal consistency of individual tree segmentation on deciduous stands using digital aerial photogrammetry (DAP) and unmanned aerial systems (UAS). Remote Sens. 11(7): 739. doi:10.3390/rs11070739.

Økseter, R., O.M. Bollandsås, T. Gobakken and E. Næsset. 2015. Modeling and predicting aboveground biomass change in young forests using multi-temporal airborne laser scanner data. Scand. J. For. Res. 30(5): 458-469. doi:10.1080/02827581.2015.1024733.

Perron, R. 2018. Identification automatisée par lidar aérien de l'espèce d'arbres individuels en forêt boréale aménagée, M.Sc. Thesis, Université du Québec à Montréal, May 2018, 97 p.

Pokharel, B., J.P. Dech, A. Groot and D.Pitt. 2014. Ecologicallybased predictive modeling of wood quality characteristics of black spruce (Picea mariana (Mill.) B.S.P.) in boreal landscapes of Northern Ontario. Can. For. J. Res. 44: 465-475.

Poudel, K.P., J.W. Flewelling and H. Temesgen. 2018. Predicting volume and biomass change from multi-temporal LiDAR sampling and remeasured field inventory data in Panther Creek Watershed, Oregon, USA. Forests. 9(1): 28. https://doi.org/10.3390/f9010028.

Priedhorsky, W.C., R.C. Smith and C. Ho. 1996. Laser ranging and mapping with a photon-counting detector. Appl. Opt. 35(3): 441-452. doi:10.1364/AO.35.000441.

Queinnec, M., P. Tompalski, D.K. Bolton and N.C. Coops. 2021. FOSTER - An R package for forest structure extrapolation. PLOS1. 16(1) 10.1371/journal.pone.0244846

Ravaglia, J., A. Bac and R.A. Fournier 2017. Extraction of tubular shapes from dense point clouds and application to tree reconstruction from laser scanned data. Comput. Graph. 66, 23-33

Ravaglia, J., R. Fournier, A. Bac, C. Véga, J.-F. Côté, A. Piboule and U. Rémillard. 2019. Comparison of Three Algorithms to Estimate Tree Stem Diameter from Terrestrial Laser Scanner Data. Forests 10(7): 599. doi:10.3390/f10070599.

Roussel, J.R., M. Béland, J. Caspersen and A. Achim. 2018. A mathematical framework to describe the effect of beam incidence angle on metrics derived from airborne LiDAR: The case of forest canopies approaching turbid medium behaviour. Remote Sens. Environ. 209: 824-834. doi:10.1016/j.rse.2017.12.006.

Roussel, J.R., J. Caspersen, M. Béland, S. Thomas and A. Achim. 2017. Removing bias from LiDARbased estimates of canopy height: Accounting for the effects of pulse density and footprint size. Remote Sens. Environ. 198: 1-16. doi:10.1016/j.rse.2017.05.032.

Roussel, J., D. Auty, N.C. Coops, P. Tompalski, T.R.H. Goodbody, A.S. Meador, J. Bourdon, F. de Boissieu and A. Achim. 2020. lidR: An R package for analysis of airborne laser scanning (ALS) data. Remote Sens. Environ. 251: 112061. https://doi.org/ 10.1016/j.rse.2020.112061.

Schmidt, A., R.A. Fournier, J.E. Luther and M. Trudel. 2020. Development of a mapping framework for ecosystem services: The case of sediment control supply at a watershed scale in Newfoundland, Canada. Ecol. Indic. 117: 105618. doi:10.1016/j.ecolind.
2020.106518.

Schreier, H., J. Lougheed, C. Tucker and D. Leckie. 1985. Automated measurements of terrain reflection and height variations using an airborne infrared laser system. Int. J. Rem. Sens. 6: 101-13 Solberg, S., H. Kvaalen and S. Puliti. 2019. Age-independent site index mapping with repeated singletree airborne laser scanning. Scand. J. For. Res. 34(8): 763-770. doi:10.1080/02827581 .2019 .1616814 .

Swatantran, A., H. Tang, T. Barrett, P. Decola and R. Dubayah. 2016. Rapid, high-resolution forest structure and terrain mapping over large areas using single photon LiDAR. Sci. Rep. 6(1): 28277. doi:10.1038/srep28277.

Tompalski, P., N.C. Coops, J. White and M. Wulder. 2016. Enhancing forest growth and yield predictions with airborne laser scanning data: Increasing spatial detail and optimizing yield curve selection through template matching. Forests. 7(11): 255. doi:10.3390/f7110255.

Tompalski, P., N.C. Coops, P. Marshall, J. White, M. Wulder and T. Bailey. 2018. Combining multidate airborne laser scanning and digital aerial photogrammetric data for forest growth and yield modelling. Remote Sens. 10(9): 347. https://doi.org/10.3390/ rs10020347.

Tompalski, P., J. Rakofsky, N.C. Coops, J.C. White, A.N.V. Graham and K. Rosychuk. 2019. Challenges of Multi-Temporal and Multi-Sensor Forest Growth Analyses in a Highly Disturbed Boreal Mixedwood Forests. Remote Sens. 11(18): 2102. doi:10.3390/ rs11182102.

Tompalski, P., Coops, N.C., White, J.C., Goodbody, T.R.H., Hennigar, C.R., Wulder, M.A., Socha, J., Woods, M.E., 2021. Estimating Changes in Forest Attributes and Enhancing Growth Projections: a Review of Existing Approaches and Future Directions Using Airborne 3D Point Cloud Data. Current Forestry Reports. https://doi.org/10.1007/s40725-021-00135-w

Townshend, E., B. Pokharel, A. Groot, D. Pitt and J. Dech. 2015. Modeling wood fibre length in black spruce (Picea mariana (Mill.) BSP) based on ecological land classification. Forests. 6: 3369-3394. van Ewijk, K., P. Treitz, M. Woods, T. Jones and J. Caspersen. 2019. Forest site and type variability in ALS-based forest resource inventory attribute predictions over three Ontario forest sites. Forests. 10(3): 226. doi:10.3390/f10030226.

van Ewijk, K., P. Tompalski, P. Treitz, N.C. Coops, M. Woods(ret.) and D. Pitt (ret.). 2020. Transferability of ALSderived forest resource inventory attributes between an eastern and western Canadian boreal forest mixedwood site. Can. J. Remote Sens. 46(1): 1-23. doi:10.1080/07038992.2020.1769470.

van Lier, O.R., J.E. Luther, J.C. White, R.A. Fournier and J.-F. Côté. 2021. Effect of scan angle on ALS metrics and area-based predictions of forest attributes for balsam fir dominated stands. Forestry: An International Journal of Forest Research. (in review) Vastaranta, M., V. Kankarre, M. Holopainen, X. Yu, J. Hyyppä and H. Hyyppä. 2012. Combination of individual tree detection and area-based approach in imputation of forest variables using airborne laser data. ISPR J. Photogram. Remote Sens. 67: 73-79.

Wang, Y., J. Hyyppa, X. Liang, H. Kaartinen, X. Yu, E. Lindberg, J. Holmgren, Y. Qin, C. Mallet, A. Ferraz, H. Torabzadeh, F. Morsdorf, L. Zhu, J. Liu and P. Alho. 2016. International benchmarking of the individual tree detection methods for modeling 3-D canopy structure for silviculture and forest ecology using airborne laser scanning. IEEE Trans. Geosci. Remote Sens. 54(9): 5011-5027. https://doi.org/10.1109/TGRS.2016.2543225

White, B., J. Ogilvie, D.M.H. Campbell, D. Hiltz, B. Gauthier, H.K.H. Chisholm, H.K. Wen, P.N.C. Murphy and P.A. Arp. 2012. Using the cartographic depth-to-water index to locate small streams and associated wet areas across landscapes. Can. Water Resour. J. 37(4): 333-347. 